\title{
Shallow Water Table-induced Soil Degradation of a Lacustrine Cultivated Soil
}

\author{
Osama R. Abd El-kawy and Ramzy M. R. Hedia \\ Soil and Water Sciences Department, Faculty of Agriculture, Alexandria University, \\ Alexandria, Egypt
}

\begin{abstract}
T AND degradation is a world challenge for sustainable agricultural production and food $\checkmark$ security. This study aimed at evaluating the impact of shallow water table conditions on the soil degradation rate of Abis Experimental Research Station, Alexandria Governorate, Egypt. Soil salinization, sodification and water logging conditions were assessed through collecting surface $(0-30 \mathrm{~cm})$ and subsurface $(30-60 \mathrm{~cm})$ soil samples and water table samples in 2016 . The data obtained were compared with a previous survey study in 2007 and the salinization, sodification and water logging index rates were calculated. Generally, mean values of EC (dS $\mathrm{m}^{-1}$ ) and ESP (\%) increased and water table depth decreased with high spatial variability and more areas suffered from salinity and sodicity in 2016 compared to 2007 . Within a period of nine years, $46 \%$ and $47 \%$ of the cropland area were converted from "non to slightly saline" to "moderately to highly saline" soil in the surface and subsurface layers, respectively. About $45 \%$ and $46 \%$ of the area were deteriorated and turned into sodic soils in the surface and subsurface layers, respectively.The water-table intruded much more to the soil surface where $95 \%$ of the cropland area had water-table depth of 50-100 $\mathrm{cm}$. The salinization rate index was $<2 \mathrm{dS} \mathrm{m}^{-1} /$ year (Non to slight) for the all observations. $35 \%$ of the area showed moderate sodification rate (1-2 increase in ESP/year) and only 4\% with high sodification rate (2-3 increase in ESP/year). A moderate (1-3 cm decrease/year) and high (3-5 cm decrease/year) water logging rates were observed in $46 \%$ and $28 \%$ of the area, respectively, which were mostly found in the Eastern part of Abis farm.
\end{abstract}

Keywords: Soil degradation, Water logging, Soil salinization and sodification.

\section{Introduction}

Land degradation is an environmental issue that faces the world (UNCED 1992; UNEP 2007). It has negative impacts on agricultural productivity, ecological functions and hence the life quality (Taddese 2001; Masoudi et al. 2018). About 25\% reduction of the biomass production is claimed to be induced by many parameters related to environmental factors and human activities on different scales of time and space (Taddese 2001; Zehtabian and Jafari 2002; Barzani and Khairulmaini 2013; Masoudi and Amiri 2015). Arid, semi-arid and dry sub-humid regions are the mostsusceptible to land degradation problems (Eliasson et al. 2003; Pan and Li 2013; Masoudi 2010 and 2014). Soil degradation was the main subject of land degradation assessment. Many studies have concluded that to evaluate land degradation is not an easy task. Therefore, different evaluation methods based on estimating the vulnerability to desertification and erosion or the actual (present) state of soil degradation should be tested (Oldeman 1992; Lal et al. 1997; Eswaran and Reich 1998). Assessment of land degradation includes three aspects (FAO-UNEP, 1984); i) current or present status, ii) trend or rate and iii) vulnerability to hazard or risk. In addition, the use of Geographic Information Systems (GIS)is helpful to manipulate and analyze soil survey andenvironmental data for solving land degradation problems. This enables us to determine future hazards through overlaying multiple data 
domains (Rangzan et al., 2008, Miehe et al., 2010, Higginbottom and Symeonakis, 2014 and Pinzon \& Tucker, 2014).

Lacustrine deposits developed in north Egypt are considered sedimentary rock formations which were formed in the bottom of ancient lakes. Commonly, the sediments were carried to the basin via rivers or streams to deposit in oxbow, riftgraben,crater, or glacial lakes (Krzic et al., 2010). Within the geologic time span, these lakes dry up when they no longer receive river or stream waters, leaving the sedimentary beds. Such deposits are composed of highly laminated and well sorted silt and clay particles. Carbonates can also exist within these deposits.

Abis region is an agricultural production region located in the Northeastern part of Alexandria Governorate. Abis soil represents a part of the lacustrine deposits in Egypt (Said, 1962) with an average sandy-clay-loam soil texture of the surface soil layer and a saline, shallow water table level (40-110 cm). Several environmental, managerial, and human activity parameters in Abis region contributed to land degradationand reduction of agricultural productivity (Atta, 2010, Hedia, 2016 and Kamh, 2016).While shallow water table in Abis region was found to be responsible for the secondary salinization problem and water logging (Atta, 2010; Hedia, 2016), low yield of various crops and sustainable soil productivity is influenced by improper management practices (Kamh, 2016). Karimov et al, (2014) found that shallow water table contributed to $45-47 \%$ of the total evapotranspiration of winter wheat and this was associated with an increase evaporation loss and the buildup of soil salinity. Soil salinity induced by shallow water table is influenced by the soil texture and its vertical homogeneity which mainly determine the hydraulic properties and the flow patterns of water and solutes along the soil profile (Li et al., 2014).

Therefore, the objective of this study was to evaluate the impact of shallow water table conditions on the soil degradation rate of Abis Experimental Research Station.

\section{Description of the study area}

The study area is represented by the Experimental Research Station, Alexandria University, in Abis sector. It is located Northeast of Alexandria Governorate (Egypt) and bounded by Latitudes $31^{\circ} 12^{\prime} 36^{\prime \prime}$ and $31^{\circ} 13^{\prime} 8^{\prime \prime}$ ' N; and Longitudes $29^{\circ} 58^{\prime}$ '24" and $29^{\circ} 59^{\prime} 36^{\prime \prime}$ E (Fig. 1). The farm total area is about 160 ha (400 Feddans), the cropped area represents about $85 \%$ (135 ha) and the remaining land is dedicated for the farm services (Animal and poultry production, administration and store building). The farm land is at an average elevation of $1 \mathrm{~m}$ under mean sea level and has a flat sloping topography. Climatic data reveal that rainfall ranges between 50 and 285 $\mathrm{mm} /$ year on October and February, respectively. The summer temperature varies between $21{ }^{\circ} \mathrm{C}$ and $32{ }^{\circ} \mathrm{C}$ while in winter the temperature varies between $9{ }^{\circ} \mathrm{C}$ to $18{ }^{\circ} \mathrm{C}$. Relative humidity ranges between $10 \%$ in December and $70 \%$ during summer. The soil of the study area are recently formed and weakly developed, which reflects the prevailing dry climatic conditions.

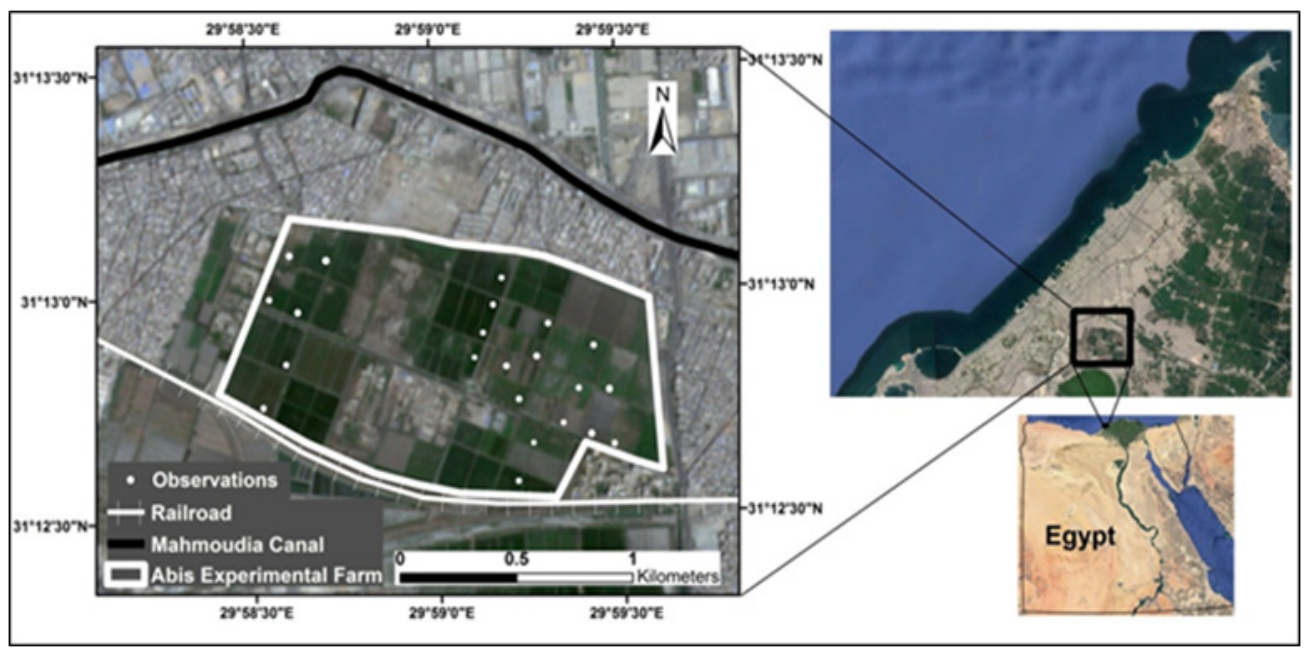

Fig. 1. General location of the study area and locations of soil observations 
According to Atta (2010) and Said (1962), the farm soil could be classified into the soil suborder Fluvents, since it developed from lacustrine deposits with stratified mode of formation. The surface soil layer is characterized by the soil texture "clay loam" and "sandy clay loam" with CEC value ranges from 22 to $29 \mathrm{meq} / 100 \mathrm{gm}$ soil, while the sub-soil layer (40 to $50 \mathrm{~cm}$ from soil surface) is clay mixed with shells (Darwish, 1977; Al-Atar, 1980). The farm is irrigated from Al-Mahmodia canal $\left(\mathrm{EC}=0.6 \mathrm{dS} \mathrm{m}^{-1}\right)$ using furrow and/or strip irrigation techniques and a tile drainage network system was installed.

\section{Materials and Methods}

Field work and laboratory analyses

This research work is based on collected soil survey data achieved in the winter season of 2007 (Atta, 2010) and soil survey data collected in this study, where the soil survey process was only performed for the crop land area which is separated into two parts by the farm land services (Fig. 1). During the field work, on March 2016, twenty two soil observation wells were assigned and georeferenced using GPS and drilled using the soil auger tool, where the locations of the selected observation wells in 2007 and 2016 are identically the same (Fig. 1). The growing crops in the investigated soils in 2016 were wheat, barley, clover, garlic, and previous rice. The water table level was addressed in its natural equilibrium state and soil samples were collected from the surface $(0-30 \mathrm{~cm})$ and subsurface $(30-$ $60 \mathrm{~cm}$ ) layers. A water table sample was collected from each observation and an irrigation water sample was collected from the main irrigation canal. Field inspections indicated that the tile drainage systemwas at low efficiency and needs maintenance, especially in the Western part of the farm. Soil and water samples were laboratory analyzed according to Page et al. (1982) and Richards (1954) which is the same methodology followed in 2007. The analyses included electrical conductivity (EC), $\mathrm{pH}$, soluble cations and anions. The exchangeable sodium percent (ESP) was calculated from sodium adsorption ratio (SAR). Soil analyses were performed in soil paste. ESP was calculated according to the following equation:

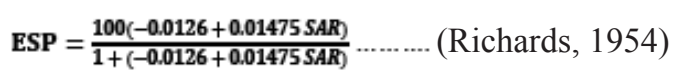

\section{Statistical analysis}

Descriptive statistics (mean, minimum, maximum, range, standard deviation, and coefficient of variation) and the test for significant differences between means using the F-test at 0.05 , assuming unequal variances of groups were conducted using the CoStat statistical analysis package ver. 6.303 (Cohort, 2004).

\section{Soil mapping}

Maps of soil salinity, soil alkalinity, and the depth to water table were created through interpolation processes using the Inverse Distance Weighting (IDW) method in $\operatorname{ArcGIS}^{\circledR}$ version 9.3 (ESRI, 2008). Mapswereinitiatedusing the resultedsoil analyses data for both 2007 and 2016 based on the same interpolation process $I D W$. Soil maps of 2007 were then used as base maps for the study.

\section{Soil degradation assessment}

A comparison study was performed between the two data sets, where land degradation status was assessed and described for 2007 (as a study base line) and 2016, and then the annual rate of land degradation was calculated and described. In this process, we followed the methodology and ratings developed by FAO (1979 and 1988); UNEP 1991; and UNSW, 2007) and applied by Abdel Kawy and Ali (2012), where the soil salinity, soil sodicity and water logging parameters were included in the assessment of land degradation. The rate of soil degradation was estimated for each soil parameteraccording to the following equation:

$$
R S D=\left[\left(P V_{2016}-P V_{2000}\right) / 9\right]
$$

where $R S D$ is rate of soil degradation for the soil parameter, $P V_{2016}$ is the parameter value in 2016, $P V_{2007}$ is the parameter value in 2007 , and the value " 9 " refers to the duration period in years. Tables (1 and 2) show the classes and description used for the soil degradation assessment. Maps of status and rate of soil degradation were created using ArcGIS.

\section{Results And Discussion}

\section{Soil salinization and sodification}

Descriptive statistics of the measured soil EC, pH, ESP and water table depth (Tables3) revealed that the mean EC of the surface layer in $2016\left(5.48 \mathrm{dSm}^{-1}\right)$ was significantly higher than that in $2007(3.09 \mathrm{dS} / \mathrm{m})$. The coefficient 
TABLE 1. Classes and description of soil degradation hazards for soil salinity, soil sodicity and water logging

\begin{tabular}{|c|c|c|c|c|c|}
\hline \multirow[b]{2}{*}{ Degradation status } & \multirow[b]{2}{*}{ Indicator } & \multicolumn{4}{|c|}{ Degradation rate } \\
\hline & & $\begin{array}{c}\text { Non to } \\
\text { slight }\end{array}$ & Moderate & High & Very high \\
\hline Salinization(FAO, 1988) & $\begin{array}{c}\mathrm{EC}(\mathrm{dS} / \mathrm{m}) \\
(\text { In soil paste) }\end{array}$ & $<4$ & $4-8$ & $8-16$ & $>16$ \\
\hline Sodification(UNSW, 2007) & ESP & $<10$ & $10-15$ & $15-25$ & $>25$ \\
\hline $\begin{array}{l}\text { Water logging } \\
\text { (Abdel Kawy and Ali 2012) }\end{array}$ & $\begin{array}{l}\text { Water table } \\
\text { level }(\mathrm{cm})\end{array}$ & $>150$ & $150-100$ & $100-50$ & $<50$ \\
\hline
\end{tabular}

TABLE 2. Classes and description of soil degradation rate for soil salinity, soil sodicity and water logging

\begin{tabular}{|c|c|c|c|c|c|}
\hline \multirow[b]{2}{*}{ Type } & \multirow[b]{2}{*}{ Indicator } & \multicolumn{4}{|c|}{ Degradation rate } \\
\hline & & $\begin{array}{l}\text { Non to } \\
\text { slight }\end{array}$ & Moderate & High & Very high \\
\hline Salinization(FAO, 1979) & $\begin{array}{l}\text { Increase in (EC) } \\
\mathrm{dS} / \mathrm{m} / \text { year (in soil } \\
\text { paste) }\end{array}$ & $<2$ & $2-3$ & $3-5$ & $>5$ \\
\hline Sodification(FAO, 1979) & $\begin{array}{l}\text { Increase in ESP } \\
\text { (percent/ year) }\end{array}$ & $<1$ & $1-2$ & $2-3$ & $>3$ \\
\hline $\begin{array}{l}\text { Water logging } \\
\text { (Abdel Kawy and Ali, 2012) }\end{array}$ & $\begin{array}{l}\text { Decrease in water } \\
\text { table }(\mathrm{cm} / \text { year })\end{array}$ & $<1$ & $1-3$ & $3-5$ & $>5$ \\
\hline
\end{tabular}

of variation $(\mathrm{CV}, \%)$ of measured $\mathrm{EC}$ values in 2016 was higher than that in 2007 indicating more variability in the EC of the surface layer in 2016 than that in 2007. The maximum EC values for the surface layer recorded 9.16 and $19.60 \mathrm{dSm}^{-1}$ for 2007 and 2016, respectively. The subsurface layer showed the same trend in the mean and the range of measured EC. F-test at 0.05 revealed that there were no significant differences between the mean values of EC of the surface and subsurface layers in 2007 or 2016 (Table 4). The spatial and temporal differences of mean $\mathrm{pH}$ values were not significant, where the mean values of the surface and subsurface layers are very close to each other's as well as the CV values (Table 3). Strong variations can be noticed in the ESP (\%) for the surface and subsurface layers and between the year 2007 and 2016 indicated by the high CV values. The mean ESP values were significantly different for both the surface and subsurface layers in 2007 but not significant in 2016 (Table 4). Mean ESP values of the surface and subsurface layers in 2016 were significantly higher than those in 2007 (Table 3). The subsurface layer generally showed higher mean values (11.13 and $17.5 \%$ in 2007 and 2016, respectively) than those of the surface layer (9.31 and $15.62 \%$ in 2007 and 2016 , respectively). The mean value of the water table (Table 3) was found to raise closer to the soil surface in $2016(71.77 \mathrm{~cm})$ compared to that in $2007(91.14 \mathrm{~cm})$, however, no significant difference was found between them. The minimum water table depth recorded 60 and 44 $\mathrm{cm}$ in 2007 and 2016, respectively. The maximum depth recorded 130 and $120 \mathrm{~cm}$ in 2007 and 2016, respectively, and the $\mathrm{CV}$ values are very close and had moderate values $(20.31$ and $25.83 \%$ in 2007 and 2016, respectively).

The surface and subsurface spatial distribution of soil salinity in 2007 and 2016 and their temporal changes are presented in Fig. 2. Data of soil salinity in 2007 showed that about $78 \%$ and $77 \%$ of the cropland area were non to slightly saline $(\mathrm{EC}<$ $4 \mathrm{dS} \mathrm{m}^{-1}$ ) for the surface and subsurface layers, respectively. Only $22 \%$ and $23 \%$ of the cropland area had a salinity problem $\left(\mathrm{EC}>4 \mathrm{dS} \mathrm{m}^{-1}\right)$ for the surface and subsurface layers, respectively. It 
TABLE 3. Descriptive statistics of soil EC, pH, ESP and water table depth for 2007 and 2016

\begin{tabular}{|c|c|c|c|c|c|c|c|c|}
\hline Parameter & Signifcance $^{+}$ & Year & Mean $^{++}$ & $\begin{array}{l}\text { Standard } \\
\text { Deviation }\end{array}$ & Range & Minimum & Maximum & C.V \\
\hline & \multicolumn{8}{|c|}{ Surface soil } \\
\hline \multirow{2}{*}{$\mathrm{EC}\left(\mathrm{dS} \mathrm{m} \mathrm{m}^{-1}\right)$} & \multirow{2}{*}{$* *$} & 2007 & $3.09 \mathrm{~b}$ & 2.29 & 8.14 & 1.02 & 9.16 & 74.20 \\
\hline & & 2016 & $5.48 \mathrm{a}$ & 4.63 & 18.85 & 0.76 & 19.6 & 84.56 \\
\hline \multirow{2}{*}{$\mathrm{pH}$} & \multirow{2}{*}{ NS } & 2007 & $8.37 \mathrm{a}$ & 0.21 & 0.97 & 7.62 & 8.59 & 2.47 \\
\hline & & 2016 & $8.06 a$ & 0.25 & 0.84 & 7.62 & 8.46 & 3.15 \\
\hline \multirow{2}{*}{ ESP \% } & \multirow{2}{*}{$* *$} & 2007 & $9.31 b$ & 5.11 & 19.87 & 1.20 & 21.07 & 54.93 \\
\hline & & 2016 & $15.62 \mathrm{a}$ & 11.72 & 44.81 & 1.08 & 45.88 & 75.02 \\
\hline \multirow{2}{*}{$\begin{array}{l}\text { Water Table } \\
\qquad(\mathrm{cm})\end{array}$} & \multirow{2}{*}{ NS } & 2007 & $91.14 \mathrm{a}$ & 18.51 & 70 & 60 & 130 & 20.31 \\
\hline & & 2016 & $71.77 \mathrm{a}$ & 18.54 & 76 & 44 & 120 & 25.83 \\
\hline & \multicolumn{8}{|c|}{ Subsurface soil } \\
\hline \multirow{2}{*}{$\mathrm{EC}\left(\mathrm{dS} \mathrm{m} \mathrm{m}^{-1}\right)$} & \multirow{2}{*}{$*$} & 2007 & $3.29 b$ & 2.47 & 10.69 & 1.34 & 12.03 & 74.91 \\
\hline & & 2016 & $4.47 \mathrm{a}$ & 3.58 & 10.85 & 0.15 & 11 & 79.98 \\
\hline \multirow{2}{*}{$\mathrm{pH}$} & \multirow{2}{*}{ NS } & 2007 & $8.32 \mathrm{a}$ & 0.20 & 0.98 & 7.54 & 8.52 & 2.49 \\
\hline & & 2016 & $8.03 a$ & 0.28 & 0.92 & 7.5 & 8.42 & 3.36 \\
\hline \multirow{2}{*}{ ESP \% } & \multirow{2}{*}{$*$} & 2007 & $11.13 b$ & 8.26 & 36.12 & 0.48 & 36.6 & 74.14 \\
\hline & & 2016 & $17.50 \mathrm{a}$ & 14.56 & 58.31 & 1.13 & 59.44 & 83.19 \\
\hline
\end{tabular}

+ Significant difference between the data of 2007 and 2016 according to F-test at 0.05

${ }^{++}$Means followed by the same letter are not significantly different.

TABLE 4. Statistical significance of surface and subsurface means of EC, pH and ESP for 2007 and 2016 using F-test at 0.05

\begin{tabular}{|c|c|c|c|c|}
\hline Year & Layer & $\begin{array}{c}\text { EC } \\
\left(\mathbf{d S ~ m}^{-1} \mathbf{)}\right.\end{array}$ & $\mathbf{p H}$ & $\begin{array}{c}\text { ESP } \\
\mathbf{\%}\end{array}$ \\
\hline \multirow{2}{*}{2007} & Surface & $3.09 \mathrm{a}$ & $8.37 \mathrm{a}$ & $9.31 \mathrm{~b}$ \\
& Subsurface & $3.29 \mathrm{a}$ & $8.32 \mathrm{a}$ & $11.13 \mathrm{a}$ \\
\multirow{2}{*}{2016} & Surface & $5.48 \mathrm{a}$ & $8.06 \mathrm{a}$ & $15.62 \mathrm{a}$ \\
& Subsurface & $4.47 \mathrm{a}$ & $8.03 \mathrm{a}$ & $17.50 \mathrm{a}$ \\
\hline
\end{tabular}

was also observed that the salinity problem was concentrated in the Western part of the area for both layers. In 2016, soil salinity problemsshowed to be increased in both the surface and subsurface layers. Data revealed that more areas suffered from excess salinity, where $68 \%$ and $70 \%$ of the cropland area had EC> $4 \mathrm{dS} \mathrm{m}^{-1}$ (moderately to very highly saline) for the surface and subsurface soil layers, respectively. It was also found that the highly saline soil expanded in the Western part of the area. This means that in the period from 2007 to 2016 almost $46 \%$ and $47 \%$ of the cropland area were converted from "non to slightly saline" to "moderately to highly saline" soil in the surface and subsurface layers, respectively.

Soil survey data in 2007 showed that only $3 \%$ and $8 \%$ of the cropland area suffered from soil sodicity problems (ESP $>15 \%$ ) for the surface and subsurface layers, respectively (Fig. 3). On the other hand, the sodicity problem showed to extend to larger areas in the farm in 2016. It was found that $48 \%$ and $54 \%$ of the cropland area had ESP $>15 \%$ for the surface and subsurface layers, respectively. This means that about $45 \%$ and $46 \%$ of the area were deteriorated and turned into 


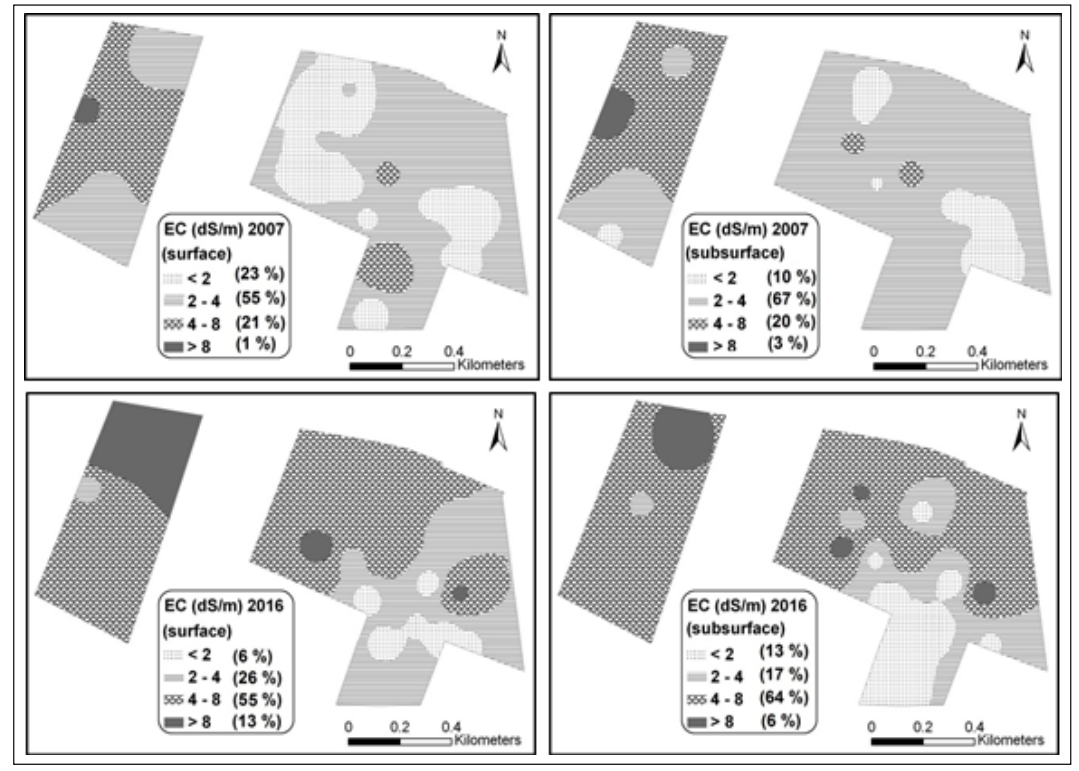

Fig. 2. Surface and subsurface spatial distribution of soil salinity in 2007 and 2016

sodic soils in the surface and subsurface layers, respectively.

These results are in accordance with the conclusion of Darwish (1977) and Al-Attar (1980), the main driver of soil salinity and sodicity problems in Abis region is the poorly developed drainage system. In this case, much amount of drainage water usually release to drains during rice season cultivation in the region. This is combined with the little slope degrees and small leveling differences among the drain tiles as well as Alkalaa drain (the main drain of Abis region) resulted in a flow back of drainage water into Abis farm drains, which keeps the water table near soil surface. In addition, the increase and extension of soil salinity and sodicity problems may be explained by the low efficient management practice in the farm that control soil salinity and sodicity problems. It was also found that the Western part of the farm was mostly affected with sodicity in 2016 in both the surface and subsurface layers.This may be regarded to the cropping pattern followed in the farm, where the Western part is dedicated for rice cultivation which may increase salt accumulation in soil especially with the low efficiency of the tile drainage system.

Water logging and salinity of Water-table

From the descriptive statistics of water table analyses in 2016 (Table 5), it was found that the $\mathrm{pH}$ was the least variable parameter with a mean value of $7.14(\mathrm{CV}=3.50 \%)$. However, the variability of EC, concentrations of major soluble ions and SAR were moderate tohigh (CV from 16.10 to 208 $\%)$. The mean value of the water table salinity was $15.67 \mathrm{dS} \mathrm{m}^{-1}$ with a minimum and maximum values of 1.50 and $35.20 \mathrm{dSm}^{-1}$, respectively $(\mathrm{CV}=68.03)$. The mean SAR recorded 22.08 with a minimum and maximum values of 3.66 and 51.41, respectively $(\mathrm{CV}=69.25)$. Water table analysis data were not available for 2007.

Water logging problems are strongly related to the depth of water-table from the soil surface (Kamh 2016 and Cox \& McFarlane, 1995). Figure 4 shows the spatial distribution of depth to watertable in the cropland area for 2007 and 2016. In 2007 , most of the area $(83 \%)$ had water-table depth between 60 and $100 \mathrm{~cm}$. The situation got worse in 2016, and the water-table intruded much more to the surface in larger areas as $95 \%$ of the cropland area had water-table depth between 50 and $100 \mathrm{~cm}$. These results may indicate the poor performance of the tile drainage system installed and unsustainable irrigation management practices in the farm.

Figure 5 presents the water-table chemical analyses results for $\mathrm{EC}, \mathrm{SAR}, \mathrm{Na}^{+}$and $\mathrm{Cl}$. 


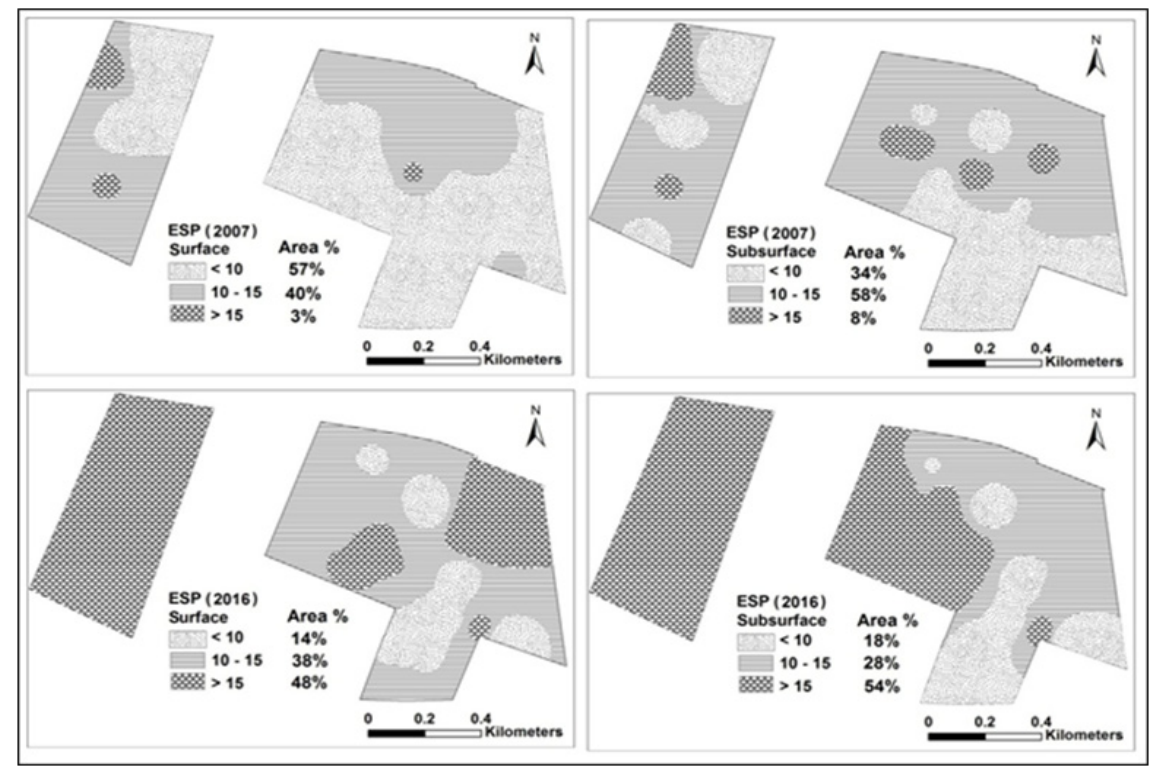

Fig. 3. Surface and subsurface spatial distribution of soil sodicity in 2007 and 2016

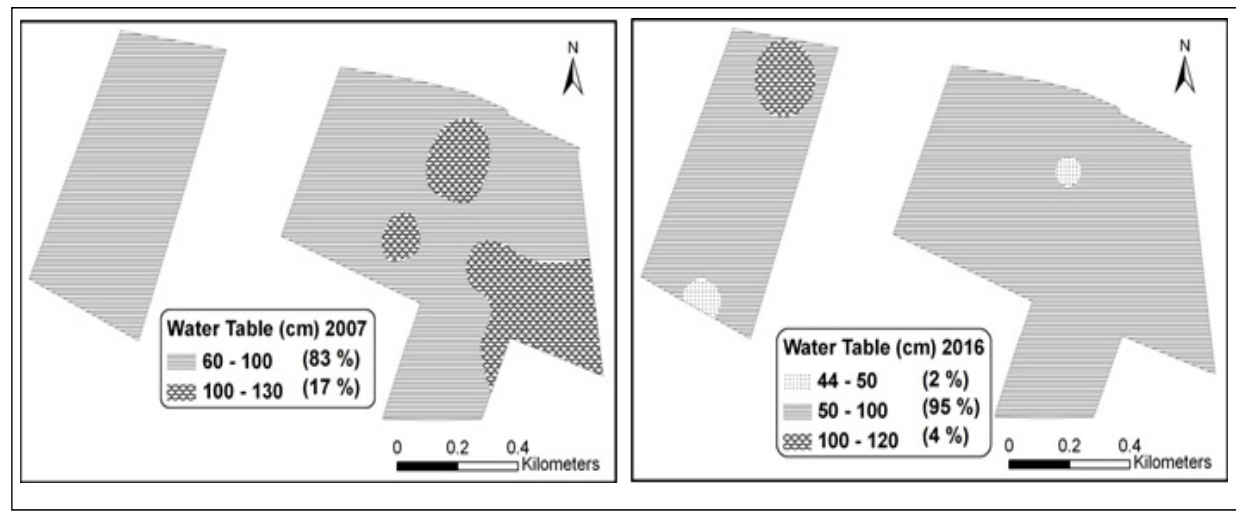

Fig. 4. Spatial distribution of depth to water-table in 2007 and 2016

TABLE 5. Descriptive statistics of Abis water table analyses for 2016

\begin{tabular}{|l|c|c|c|c|c|c|c|c|c|c|}
\hline \multicolumn{1}{|c|}{$\begin{array}{c}\text { Statistical } \\
\text { parameter }\end{array}$} & $\begin{array}{c}\mathbf{E C} \\
\mathbf{d S} \mathbf{~ m}^{-1}\end{array}$ & $\mathbf{p H}$ & $\mathbf{S A R}$ & $\mathbf{\mathbf { C a } ^ { 2 + }}$ & $\mathbf{M g}^{2+}$ & $\mathbf{C l}^{-}$ & $\mathbf{C O}_{3}^{2-}$ & $\mathbf{H C O}_{3}^{-}$ & $\mathbf{N a}^{+}$ \\
\hline Mean & 15.67 & 7.14 & 22.08 & 10.25 & 51.43 & 171.50 & 0.50 & 15.14 & 118.97 \\
Standard Deviation & 10.66 & 0.25 & 15.29 & 8.95 & 42.59 & 137.91 & 1.04 & 6.10 & 95.28 \\
\hline Range & 33.70 & 1.11 & 47.75 & 37.80 & 179.00 & 493.00 & 4.00 & 20.00 & 298.72 \\
\hline Minimum & 1.50 & 6.77 & 3.66 & 2.20 & 4.00 & 7.00 & 0.00 & 7.00 & 4.34 \\
\hline Maximum & 35.20 & 7.88 & 51.41 & 40.00 & 175.00 & 500.00 & 4.00 & 27.00 & 303.06 \\
\hline CV, \% & 68.03 & 3.50 & 69.25 & 85.65 & 16.10 & 80.41 & 208 & 40.29 & 80.09 \\
\hline
\end{tabular}


concentrations (meq $\left.\mathrm{l}^{-1}\right)$.Only one of the collected water-table samples had $\mathrm{EC}<2 \mathrm{dS} \mathrm{m}^{-1}$. About $17 \%$ of the area had water-table salinity from 2 to $8 \mathrm{dS}$ $\mathrm{m}^{-1}$ and about $83 \%$ had water-table salinity $>8 \mathrm{dS}$ $\mathrm{m}^{-1}$ (Fig. 5a). Only about $21 \%$ of the cropland area had water-table $\mathrm{SAR}<13$ and the rest of the area had water-table SAR $>13$ (Fig. 5b). This was also reflected in the spatial distribution of $\mathrm{Na}^{+}$in the surveyed area (Fig. 5c). Only about $22 \%$ of the area had $\mathrm{Na}^{+}$concentration $<64$ meq $\mathrm{l}^{-1}$ and the rest of the water-table samples representing $78 \%$ of the area had $\mathrm{Na}^{+}$concentration $>64$ and up to $303 \mathrm{meq}^{-1}$. Chloride concentration in watertable samples was found to be strongly correlated with the measured $\mathrm{EC}$ and $\mathrm{Na}^{+}$concentration in the corresponding water samples $(\mathrm{r}=0.83)$. Although about $25 \%$ of the area had water-table samples having $\mathrm{Cl}^{-}<107 \mathrm{meq}^{-1}$, the rest of the area had $\mathrm{Cl}^{-}$ $>107$ and up to $500 \mathrm{meq}^{-1}$. This may indicate the dominance of the $\mathrm{NaCl}$ salt as the main salinity component in the water-table.

\section{Soil degradation indices}

The salinization rate index was calculated for the cropland area and it was found to have a value $<2 \mathrm{dS} \mathrm{m} \mathrm{m}^{-1}$ year (Non to slight) for the all observations. The calculated sodification rate and water logging indices are presented in Fig. 6 and 7. While $60 \%$ of the cropland in the surface layer showed a none to slight rate of sodification $(<1$ increase in ESP/year), which mostly concentrates in the Eastern part, $35 \%$ of the area showed moderate sodification rate (1-2 increase in ESP/ year) and $4 \%$ with high sodification rate (2-3 increase in $\mathrm{ESP} / \mathrm{year}$ ) that mostly concentrate in the Western part of the cropland area. Compared to the surface, the subsurface layer showed higher sodification rate, wherethe area with high to very high sodification rate increased to $6 \%$ and $3 \%$ on the account of the moderate category. The areas with moderate, high, and very high sodification rates concentrate in the Western part of the farm compared with the Eastern part that had the most area $(61 \%)$ with none to slight sodification rate.

Water logging rate index (Fig. 7) was used to express the decrease of change in water-table depth from the soil surface (cm/year). $23 \%$ of the cropland area had a non to slight water logging rate $(<1 \mathrm{~cm}$ decrease/year) which is mostly found in the western part of the farm. $46 \%$ of the cropland area had a moderate water logging rate (1-3 cm decrease/year) which was mostly found in the Eastern part. In addition, $28 \%$ of the area had a high water logging rate $3-5 \mathrm{~cm}$ decrease/ year) and only $3 \%$ with very high water logging rate ( $>5 \mathrm{~cm}$ decrease/year), located in the eastern part of the farm.

In light of the evidences drawn from the results, special efforts are required to control soil salinity and sodicity problems in the study area. These efforts include enhancement of the tile drainage system efficiency developed in the farm. This will decrease the water table level and preserve more

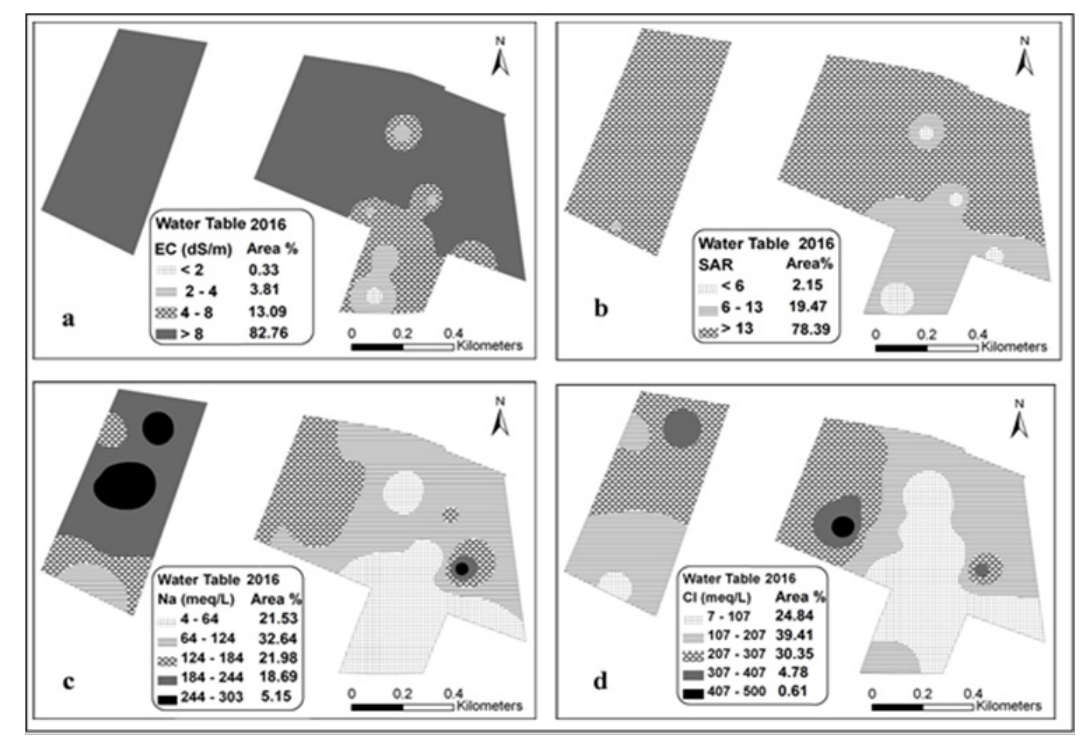

Fig. 5. Spatial distribution of the water-table parameters for 2016 

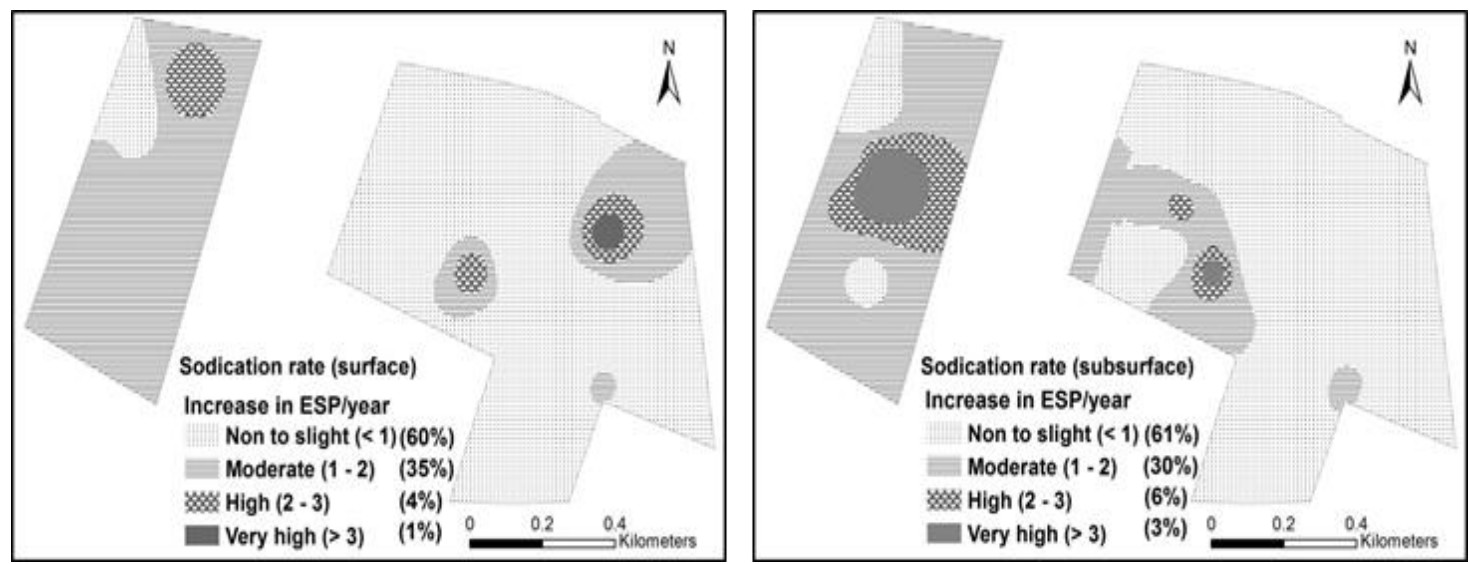

Fig. 6. Spatial distribution of the sodification rate for the surface and subsurface layers

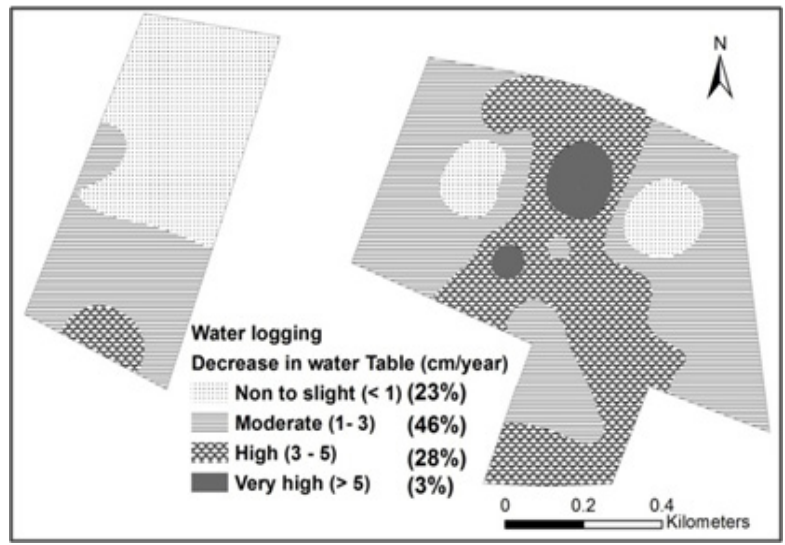

Fig. 7. Spatial distribution of the water logging rate

areas from salinization and sodification as well as increase crop productivity.

\section{Conclusion}

Field assessment of the cultivated area of Abis Experimental Research Station for soil salinity, sodicity and water table depth showed that the soil has salinity-sodicity problems induced by the shallow, saline water table. This situation was a result of the low efficiency of the tile drainage network and the improper managerial practices. Based on the data obtained in 2007 and 2016, the calculated degradation index rates revealed that the deterioration of the cultivated area is continuous and the water logging condition and sodification are getting worse. Proper measures and interventions should be adopted to increase the efficiency of the tile drainage system installed and to reclaim the salt-affected areas which was indentified in this study.

\section{References}

Abdel Kawy, W.A.M.. and Ali, R.R., (2012) Assessment of soil degradation and resilience at northeast Nile Delta, Egypt: The impact on soil productivity. The Egyptian Journal of Remote Sensing and Space Sciences. 5, 19-30.

Al-Atar, H. (1980) Report on faculty farm, Abis. Soil and Water Department, Faculty of Agriculture, University of Alexandria, Egypt. pp. 1-20 (in Arabic).

Atta, A. F. (2010) Spatial Variability and Land Evaluation of Abis Agriculture Research Station. MSc Thesis. Faculty of Agriculture, Alexandria University.

Barzani, M. and Khairulmaini, O. S

(2013) 
Desertification risk mapping of the Zayandeh Rood Basin in Iran, J. Earth Syst. Sci., 122.

Cohort. (2004) Statistical Analysis Package. CoStatver 6.303, CoHort Software. Monterey, CA, 93940, USA.

Cox, J. and McFarlane, D. (1995) The causes of waterlogging in shallow soils and their drainage in southwestern Australia. Journal of Hydrology, 167, 175-194.

Darwish, A. M. (1977) The morphological and chemical properties of Alexandria university farm. MS. Thesis. Faculty of Agriculture, University of Alexandria, Egypt.

Eliasson, A., Rinaldi, F. M., and Linde, N. (2003) Multicriteria decision aid in supporting decisions related to groundwater protection, Environ. Manag., 32, 589-601.

ESRI, (2008) Arc-GIS 9.3, 3D analyst. Redlands, CA, USA.

Eswaran, H. and Reich, P. F. (1998) Desertification: a global assessment and risk to sustainability, in: Proceedings of the 16th International Congress of Soil Science, Montpellier, France.

FAO (1988) Salt-Affected Soils and their Management. FAO Soils Bulletin, 39. FAO, Rome, Italy.

FAO (1979) A Provisional Methodology for Soil Degradation Assessment. FAO, Rome, Italy.

FAO-UNEP (1984) Provisional Methodology for Assessment and Mapping of Desertification, FAO, Rome, 84 p.

Hedia, R.M.R. (2016) Estimating Salinity of Soils from Northwest of Egypt using Different Soil-to-Water Ratio Extracts. Alex. Sci. Exch. J. 37 (3), 372-384.

Higginbottom, T. P. and Symeonakis, E. (2014) Assessing land degradation and desertification using vegetation index data: current frameworks and future directions, Remote Sens. Basel, 6, 9552-9575.

Kamh, K. (2016) Impact of Agricultural Practices on Soil Productivity and Sustainability of Abis Experimental Research Station (AbisERS), Egypt. Alex. J. Agr. Sci., 61, 37-49.

Karimov, A. Kh., Simunek, J., Hanjra, M. A., Avliyakulov, M., Forkutsa, I. (2014) Effects of the shallow water table on water use of winter wheat and ecosystem health: Implications for unlocking the potential of groundwater in the Fergana Valley (Central Asia). Agric. Water Manag. 131, 57-69.
Krzic M., Watson, K., Grand, S., Bomke, A., Smith, S., Dyanatkar, S., Crowley, C., and Lascu, G. (2010) Soil Formation and Parent Material. The University of British Columbia, Vancouver, Thompson Rivers University, Kamloops, and Agriculture and AgriFood Canada, Summerland.

Lal, R., Winfried, E. H., Valentin, C., and Stewart, B. (1997) Methods for Assessment of Land Degradation, CRC, Boca Ration.

Li, X., Chang, S. X., and Salifu, K. F. (2014) Soil texture and layering effects on water and salt dynamics in the presence of a water table: a review. Environ. Rev. 22, 41-50.

Masoudi, M. (2014) Risk assessment of vegetation degradation using GIS, J. Agr. Sci. Tech.-Iran, 16, 1711-1722.

Masoudi, M. (2010) Risk Assessment and Remedial Measures of Land Degradation, in Parts of Southern Iran, Lambert Academic Publishing (LAP), Germany, 220 p., ISBN: 978-3-8383-77186.

Masoudi, M. and Amiri, E. (2015) A new model for hazard evaluation of vegetation degradation using DPSIR framework, a case study: Sadra region, Iran, Pol. J. Ecol., 63, 1-9.

Masoudi, M., Jokar, P., and Pradhan, B. (2018) A new approach for land degradation and desertification assessment using geospatial techniques. Nat. Hazards Earth Syst. Sci., 18, 1133-1140.

Miehe, S., Kluge, J., von Wehrden, H., and Retzer, V. (2010) Longterm degradation of Sahelian rangeland detected by 27 years of field study in Senegal. $J$. Appl. Ecol., 47, 692-700.

Oldeman, L. R. (1992) Global Extent of Soil Degradation, ISRIC Bi-Annual Report 1991-1992, pp. 19-36. ISRIC, AJ Wageningen, Netherlands.

Page, A. L., Miller, R. H. and Keeny, R. (1982) Methods of Soil Analysis. Part 2. Chemical and microbiological properties. Agron. Monograph No. 9, ASA, Madison, WI, USA.

Pan, J. H. and Li, T.Y. (2013) Extracting desertification from LANDSAT imagery based on spectral mixture analysis and Albedo-Vegetation feature space, Nat. Hazards, 25, 915-927.

Pinzon, J. E. and Tucker, C. J. (2014) A non-stationary 1981-2012 AVHRR NDVI3g time series, Remote Sens. Basel, 6, 6929-6960. 
Rangzan, K., Sulaimani, B., Sarsangi, A. R., and Abshirini, A. (2008) Change detection, mineralogy, desertification mapping in east and northeast of Ahvaz City, SW Iran using combination of remote sensing methods, GIS and ESAs model, Global $J$. Environ. Res., 2, 42-52.

Richards, R.L. (Ed.) (1954) Diagnosis and improvement of saline and alkaline soils. Agriculture Handbook No. 60, U.S Govt. Printing Office, Washington, USA.

Said, R. (1962) The Geology of Egypt. Elsevier Publishing Company, Amsterdam, 377.

Taddese, G. (2001) Land Degradation: A Challenge to Ethiopia. Environmental Management, 27, 815824.

UNCED, (1992) Managing Fragile Ecosystems: Combating Desertification and Drought, Agenda
21, Chapter 12, United Nations Conference on Environment and Development, 21, 1992.

UNEP (1991) Global assessment of soil degradation, UNEP. United Nations, GLASOG Project.

UNEP (2007) Global Environmental Outlook GEO-4, UN Environment Programme, Nairobi, 2007.

UNSW (2007) Tera GIS. University of New South Wales. Sydney, Australia. http://www.terragis. bees.unsw.edu.au/terraGIS_soil/sp_exchangeable_ sodium_percentage.html

Zehtabian, G. and Jafari, R. (2002) Evaluation of water resources degradation in Kashan area using desertification model, J. Environ. Studies, 28, 1930.

(Received:11/11/2018; accepted:30/1/2019)

\title{
تدهور التربة الناتج عن مستوى الماء الأرضى الضحل فى أرض زراعية ذات نثأة بحيرية أسامه عبد القوى و رمزى هديه

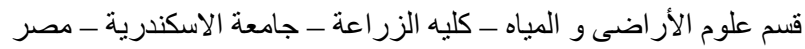

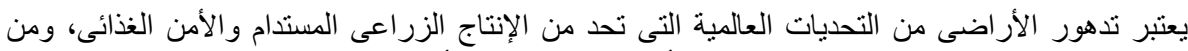

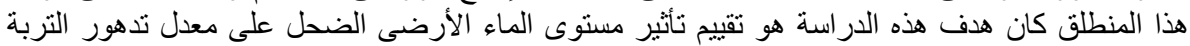

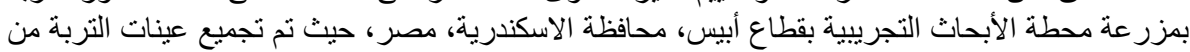

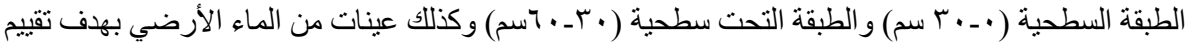

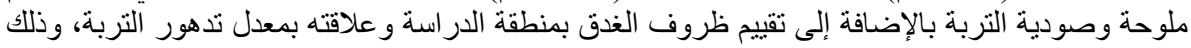

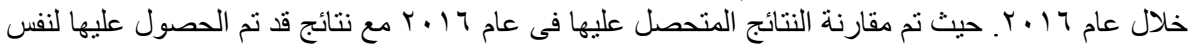

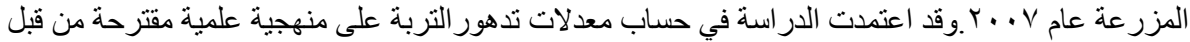

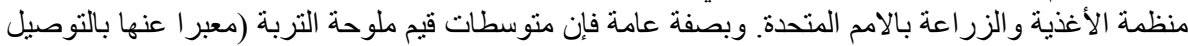

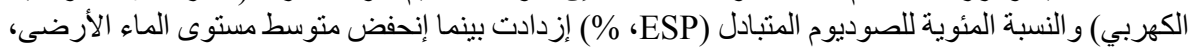

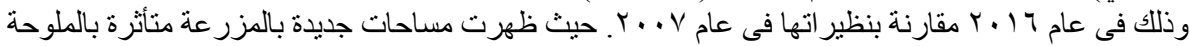

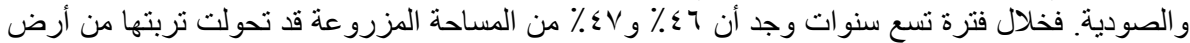

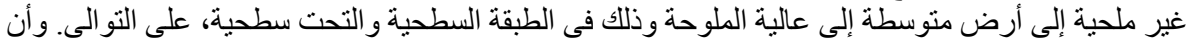

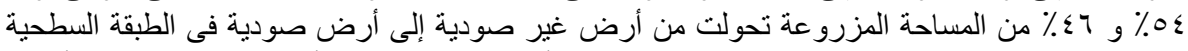

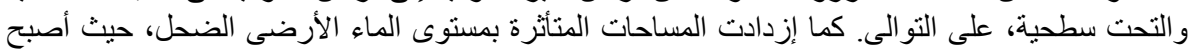

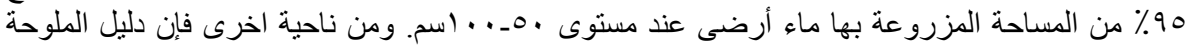

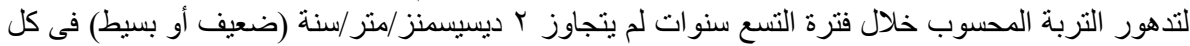

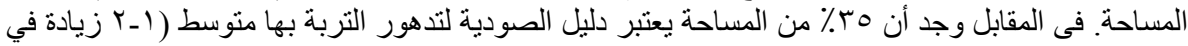

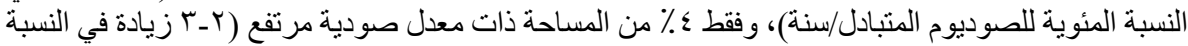

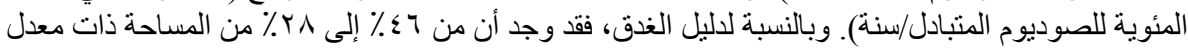

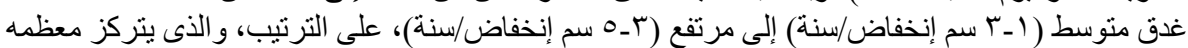
فى الجزء الثرقى من المساحة المزرو عة. إنفاضي
\end{abstract}

